\title{
ДО ПРОБЛЕМИ УДОСКОНАЛЕННЯ ПУБЛІЧНО-СЕРВІСНОЇ ДІЯЛЬНОСТІ ДЕРЖАВНОЇ ПОДАТКОВОЇ СЛУЖБИ УКРАЇНИ
}

Крилов Д. В.

\begin{abstract}
Визначено, що пріоритетними шляхами удосконалення заходів із протидії корупції $\epsilon$ : покращення фінансового та матеріально-технічного забезпечення працівників, що має передбачати забезпечення їм гідного рівня оплати праці та соціального забезпечення самих службовців та їхніх сімей; активне залучення громадськості до здійснення контрольно-наглядової діяльності за органами Державної податкової служби; здійснення міжнародного співробітництва, обмін досвідом та інформацією з міжнародними організаціями та установами, обмін практичним досвідом реалізації заходів із протидії корупції тощо; активна взаємодія Державної податкової служби з іншими правоохоронними органами України, зокрема Національною поліцією, Національним антикорупційним бюро, Національним агентством з питань запобігання корупції тощо; проведення активної роз'яснювальної роботи як серед службовців Державної податкової служби України, так і серед громадян. Враховуючи специфіку публічно-сервісної діяльності Державної податкової служби України, з метою вдосконалення матеріально-технічного забезпечення запропоновано: no-nерше, надати працівникам Державної податкової служби України сучасне технічне обладнання, що дасть змогу прискорити процедури з надання сервісних послуг, оскільки непоодинокими є скарги з боку платників податків про сервіси, що неякісно працюють; по-друге, забезпе чити кожен структурний підрозділ, який виконує публічно-сервісну діяльність, швидкісним Iнтернетом; no-mретє, створити якісні онлайн-сервіси, за допомогою яких клієнти зможуть отримувати всю необхідну інформацію. У $\mathrm{cmammi}$ на основі аналізу наукових поглядів учених та норм чинного законодавства визначено, що найбільш перспективними тенденціями удосконалення публічно-сервісної діяльності Державної податкової служби України в умовах європейської інтеграції $\epsilon:$ 1) покращення інформаційного забезпечення податкових органів; 2) поліпшення матеріально-технічного забезпечення Державної податкової служби України; 3) вдосконалення заходів із протидії корупції в органах Державної податкової служби України. Обгрунтована пріоритетність роботи законодавця за всіма визначеними вище напрямами.

Ключові слова: публічно-сервісна діяльність, Державна податкова служба України, законодавство, інформаційне забезпечення.
\end{abstract}

Определено, что приоритетными путями совершенствования мер по противодействию коррупции являются: улучшение финансового и материально-технического обеспечения работников, которое должно предусматривать обеспечение им достойного уровня оплаты труда и социального обеспечения самих служащих и их семей; активное привлечение общественности к осуществлению контрольно-надзорной деятельности за органами Государственной налоговой службы; осуществление междуна родного сотрудничества, обмен опытом и информацией с международными организациями и учреждениями, обмен практическим опытом реализации мероприятий по противодействию коррупции и т.д.; активное взаимодействие

Колесник С. П., 2019
Государственной налоговой службы с другими правоохранительными органами Украины, в частности Национальной полицией, Национальным антикоррупционным бюро, Национальным агентством по вопросам предотвращения коррупции и т.п.; проведение активной разъяснительной работы как среди служащих Государственной налоговой службы Украины, так и среди граждан. Учитывая специфику публично-сервисной деятельности Государственной налоговой службы Украины с целью совершенствования материально-технического обеспечения предложено: во-первых, предоставить работникам Государственной налоговой службы Украины современное техническое оборудование, что позволит ускорить процедуры предоставления сервисных услуг, поскольку нередки жалобы со стороны налогоплательщиков о некачественно работающем сервисе; во-вторых, обеспечить каждое структурное подразделение, выполняющее публично-сервисную деятельность, скоростным Интернетом; в-третьих, создать качественные онлайн-сервисы, с помощью которых клиенты смогут получать всю необходимую информацию. В статье на основе анализа научных взглядов учёных и норм действующего законодательства определено, что наиболее перспективными тенденциями совершенствования публично-сервисной деятельности Государственной налоговой службы Украины в условиях европейской интеграции являются: 1) улучшение информационного обеспечения налоговых органов; 2) улучшение материально-технического обеспечения Государственной налоговой службы Украины; 3) совершенствование мер по противодействию коррупции в органах Государственной налоговой службы Украины. Обоснована приоритетность работы законодателя по всем обозначенным выше направлениям.

Ключевые слова: публично-сервисная деятельность, Государственная налоговая служба Украины, законодательство, информационное обеспечение.

It has been determined that the most priority ways of improving anti-corruption measures are: improving the financial and logistical support of employees, which should provide them with a decent level of remuneration and social security for the employees themselves and their families; active involvement of the public in the control and supervision activities of the bodies of the State Tax Service; implementation of international cooperation, exchange of experience and information with international organizations and institutions, exchange of practical experience in implementing anti-corruption measures, etc.; active interaction of the State Tax Service with other law enforcement agencies of Ukraine, in particular the National Police, the National Anti-Corruption Bureau, the National Anti-Corruption Agency, etc.; active public outreach to both tax officials and citizens. Taking into account the specifics of public service activity of the State Tax Service of Ukraine in order to improve the logistics, it is proposed: first, to provide employees of the State Tax Service of Ukraine with modern technical equipment that will speed up procedures for the provision of service services, as there are often different complaints poorly performing services; second, to provide every structural unit that performs public service activities on the high-speed Internet; third, 
to create quality online services through which customers can obtain all the necessary information. In the article, based on the analysis of scientific views of scientists and norms of the current legislation, it is determined that the most promising tendencies of improvement of public service activity of the State Tax Service of Ukraine in the conditions of European integration are: 1) improvement of information support of tax authorities; 2) improvement of logistical support of the State Tax Service; 3) improvement of anti-corruption measures in State Tax Service of Ukraine bodies. The priority of the legislator's work in all the above directions is substantiated.

Key words: public service activity, State Tax Service of Ukraine, legislation, information support.

Постановка проблеми. Нині Україна перебуває на досить цікавому та складному етапі свого становлення та розвитку. Все це вимагає від законодавця проведення трансформаційних процесів у різних сферах суспільного життя. Така модернізація передбачає зміну всієї парадигми державного управління в усіх сферах діяльності суспільства. Основою таких змін мусить стати виконавча влада, діяльність якої має бути спрямована на служіння громадянам, забезпечення реалізації прав, свобод та інтересів громадян, надання адміністративних послуг. Втілення практики демократичного управління в діяльність Державної податкової служби України, як органу виконавчої влади, котрий здійснює управління у податковій сфері, вимагає відповідного правового регулювання та організації [1].

Стан дослідження. Питанню публічно-сервісної діяльності Державної податкової служби України в своїх наукових дослідженнях неодноразово приділяли увагу багато науковців, зокрема: А.Б. Лис, Л.М. Щербаківська, Л.Л. Білик, І.І. Бригілевич, С.І. Ванько, В.А. Загайний, І.Б. Коліушко, О.В. Курінний, В.О. Стоян, В.П. Тимощук, О.В. Власенко, П.В. Ворона, М.О. Пухтинський, В.В. Юзефович, Н.Л. Астапова, Н.І. Ільчанінова, М.І. Мельник, В.Л. Федоренко, Я.О. Кагляк та багато інших. При цьому вчені акцентували увагу на великій кількості проблемних аспектів, серед яких зазвичай виділяли кадрове забезпечення. Разом із тим ми переконані, що робота з кадрами не $\epsilon$ вирішальною в цьому контексті, а тому великого значення набувають i інші аспекти, яким і буде приділено увагу в рамках представленого наукового дослідження.

Саме тому мета статті - визначити напрями вдосконалення публічно-сервісної діяльності Державної податкової служби України.

Виклад основного матеріалу. Починаючи наукове дослідження, першочергово слід звернути увагу на проблему неякісного інформаційного забезпечення діяльності ДПС. Інформація - це завжди результат, продукт діяльності людини, орієнтований на створення нових відомостей або зняття відомостей з інших об'єктів матеріального або духовного світу, для об'єднання цих відомостей у певний продукт та товар, необхідний для суспільства. Визначальною $є$ теза, що для права слід використовувати якісну теорію інформації, а не кількісну, яка ігнорує зміст інформації [2]. Що ж стосується поняття «інформаційне забезпечення», то в юридичній літературі можна знайти чимало думок з приводу тлумачення цієї наукової категорії.

Інформаційне забезпечення, доводять В.М. Годун, Н.С. Орленко та М.А. Сендзюк, - це сукупність форм документів, нормативної бази і реалізованих рішень щодо обсягу, розміщення і форм організації інформації, яка циркулює в системі автоматизованого оброблення економічної інформації чи в інформаційній системі [3]. Основними принципами створення інформаційного забезпечення, на переконання вчених, $\epsilon$ : цілісність; достовірність; контроль; захист від несанкціонованого доступу; єдність і гнучкість; стандартизація та уніфікація; адаптивність; мінімізація помилок введення-виведення інформації. Розроблення інформаційного забезпечення - один з найважливіших складників розроблення інформаційної системи, яка має забезпечити: єдність і зберігання інформації, необхідної для розв'язання задач; єдність інформаційних масивів для всіх задач інформаційних систем; однократність уведення інформації та її багатоцільове використання; різні методи доступу до даних; низьку вартість витрат на зберігання та використання даних, а також на внесення змін [3].

Вдало побудоване інформаційне забезпечення, як слушно підкреслює Н.І. Сулік, - це важлива умова функціонування організації, передумова іiі необхідної гнучкості, здатності швидко реагувати на зміни у зовнішньому середовищі [4, с. 192]. Це твердження $\epsilon$ дуже актуальним стосовно публічно-сервісної діяльності Державної податкової служби України, адже лише той фахівець, який наділений всією необхідною сукупністю інформації, наприклад щодо змін у чинному законодавстві, змін у програмному забезпеченні, роботі електронного офісу тощо, може надати якісний зворотний зв'язок для клієнта та своєю чергою надати йому всю необхідну інформацію. Тож з метою покращення інформаційного забезпечення Державної податкової служби України загалом та у сфері здійснення публічно-сервісної діяльності зокрема вважаємо за доцільне:

створити необхідні умови для якісного науковометодичного забезпечення діяльності ДПС України;

забезпечити оперативний доступ працівників ДПС до оперативної інформації, а також до чинної нормативно-правової бази;

вдосконалювати систему обліку інформації, а також забезпечити ефективний контроль за ії використанням та доцільністю використання.

Наступним важливим напрямом удосконалення публічно-сервісної діяльності Державної податкової служби України в умовах європейської інтеграції $\epsilon$ покращення матеріально-технічного забезпечення. У науково-правових колах, пише Г.С. Корнієнко, під матеріально-технічним забезпеченням розуміють сукупність суспільних відносин, урегульованих нормативними актами або договорами із забезпечення матеріально-технічними ресурсами, необхідними для своєчасного та безперебійного проведення циклу робіт з виробництва, переробки й реалізації продукції, а також для виконання економічних, соціальних та інших завдань з метою задоволення певних потреб [5, с. 56]. Відповідно до точки зору В.В. Конопльова під матеріально-технічним забезпеченням необхідно розуміти сукупність суспільних відносин, урегульованих нормами різних галузей права (цивільного, адміністративного, господарського, фінансового тощо) із забезпечення їх матеріально-технічними ресурсами, необхідними для своєчасного й безперебійного виконання відповідними суб'єктами поставлених перед ними завдань [6, с. 276-278].

у контексті здійснення господарської діяльності цілями матеріально-технічного забезпечення виробни- 
цтва $€$ : своєчасне забезпечення підрозділів підприємства необхідними видами ресурсів потрібної кількості та якості; поліпшення використання ресурсів підвищення продуктивності праці, фондовіддачі, скорочення тривалості виробничих циклів виготовлення продукції, забезпечення ритмічності процесів, скорочення оборотності оборотних коштів, повне використання вторинних ресурсів, підвищення ефективності інвестицій; аналіз організаційно-технічного рівня виробництва та якості продукції у конкурентів постачальника i підготовка пропозицій щодо підвищення конкурентоспроможності матеріальних ресурсів, що поставляються, або зміну постачальника конкретного виду ресурсу [7].

Узагальнюючи все наведене вище, слід підсумувати, що матеріально-технічне забезпечення діяльності ДПС у сфері надання відповідних послуг передбачає надання цьому відомству всіх необхідних матеріальних, фінансових ресурсів для того, щоб це відомство могло якісно та ефективно виконувати обов'язки, які стоять перед ним відповідно до норм чинного законодавства. Враховуючи специфіку публічно-сервісної діяльності Державної податкової служби України, з метою вдосконалення матеріально-технічного забезпечення пропонуємо: по-перше, надати працівникам ДПС сучасне технічне обладнання, що дасть змогу прискорити процедури з надання сервісних послуг, оскільки непоодинокими є скарги з боку платників податків про сервіси, що неякісно працюють; по-друге, забезпечити кожен структурний підрозділ, який виконує публічно-сервісну діяльність, швидкісним Інтернетом; по-третє, створити якісні онлайн-сервіси, за допомогою яких клієнти зможуть отримувати всю необхідну інформацію.

I останній важливий напрям покращення публічно-сервісної діяльності Державної податкової служби України полягає в удосконаленні заходів із протидії корупції в органах ДПС. Так, на думку відомого спеціаліста у цій сфері Є.В. Невмержицького, корупція - це насамперед соціально-політичне явище, головною особливістю якого $\epsilon$ використання посадовими особами законодавчої, виконавчої та судової влади, а також громадських об'єднань, установ і організацій господарського управління всіх форм власності свого службового становища для одержання матеріальних цінностей, послуг чи пільг для себе або третіх осіб [8, с. 44]. При цьому дослідник слушно наголошує, що корупція охоплює економіку, політику, культуру, етику, мораль, усю соціальну сферу, тобто за своєю сутністю це багатоскладове соціально-політичне явище, важливою ознакою якого $€$ зумовлена цими обставинами поведінка суб'єкта правопорушення [9, с. 362; 10]. М.І. Мельник вважає, що корупція - це соціологічно-кримінологічне поняття. У загальному вигляді корупцію автор визначає як: соціальне явище, яке охоплює всю сукупність корупційних діянь, пов'язаних з неправомірним використанням особами, уповноваженими на виконання функцій держави, наданої їм влади, посадових повноважень, відповідних можливостей з метою задоволення особистих інтересів третіх осіб, а також інших корупційних правопорушень, які створюють умови для вчинення корупційних діянь чи $\epsilon$ їх приховуванням або потуранням [11; 12, с. 11-12].

Отже, корупція - це негативне соціально-економічне та політичне явище, яке заважає нормальному розвитку суспільства та перешкоджає належному функціонуванню кожного окремого органу держави, знижує рівень довіри до нього з боку суспільства тощо. А тому важливим завданням $є$ протидія цьому явищу. У широкому розумінні протидія корупції - це будь-яка діяльність у сфері соціального управління, яка, не переслідуючи спеціальної мети, сприяє зменшенню можливостей для корумпування суспільних відносин, зокрема шляхом забезпечення верховенства права, реалізації інших принципів права, розвитку демократичного суспільства та утвердження правової держави. У вузькому розумінні протидія корупції - це система заходів політичного, правового, організаційно-управлінського, ідеологічного, соціально-психологічного та іншого характеру, що мають цільове спрямування на зменшення обсягів корупції, зміну характеру корупційних проявів, обмеження взаємовпливу корупції та інших соціальних явищ і процесів, збільшення ризику для осіб, які вчиняють корупційні правопорушення, нейтралізацію дії та усунення факторів корупції, виявлення, припинення та розслідування проявів корупції, притягнення винних у скоєнні корупційних правопорушень осіб до юридичної відповідальності, поновлення законних прав та інтересів фізичних і юридичних осіб, усунення наслідків корупційних діянь. Протидія корупції $\epsilon$ безпосереднім виразом антикорупційної політики, яка визначає ідеологію і стратегію антикорупційних заходів [13].

У рамках нашого дослідження варто відзначити, що головними причинами, що спонукають працівників податкової служби до вчинення корупційних протиправних дій, є: низький рівень заробітної плати та грошового утримання працівників [14; 15]; відсутність належного соціально-правового захисту персоналу; низька оперативна обізнаність підрозділів внутрішньої безпеки та інших служб про діяльність та поведінку працівників податкових органів у податковій сфері; неналежна перевірка та реагування на наявну негативну інформацію стосовно працівників податкових органів з боку підрозділів із роботи з персоналом та їх взаємодія з безпосередніми керівниками територіальних підрозділів на місцях; недостатній рівень організаційно-практичних заходів, спрямованих на належне проведення комплектування, виховання, професійну підготовку та навчання персоналу; невчасне та формальне проведення атестацій і спеціальних перевірок персоналу; низький рівень профілактичної роботи серед працівників ДПС, неналежне виконання вимог наказів та вказівок керівництва ДПС із питань роботи з персоналом та зміцнення дисципліни і законності в діяльності податкових органів; відсутність дієвого контролю з боку керівництва відповідних структурних підрозділів за поведінкою підлеглих, виконання ними службових обов'язків у робочий час; до порушників не завжди застосовуються принципові заходи реагування, наявні суттєві прорахунки в організації контролю усуваються повільно [14].

Визначаючи напрями подолання корупції в діяльності органів Державної палаткової служби України, варто відзначити, що фахівцями вже неодноразово зверталась увага на цю проблематику. Тож ми, спираючись на аналіз наукових поглядів учених та норм чинного законодавства України, вважаємо, що пріоритетними шляхами удосконалення заходів із протидії корупції $\epsilon$ :

покращення фінансового та матеріально-технічного забезпечення працівників, що має передбачати забезпечення їм гідного рівня оплати праці та соціального забезпечення самих службовців та їхніх сімей; 
- активне залучення громадськості до здійснення контрольно-наглядової діяльності за органами ДПС;

- здійснення міжнародного співробітництва, обмін досвідом та інформацією з міжнародними організаціями та установами, обмін практичним досвідом реалізації заходів із протидії корупції тощо;

- активна взаємодія ДПС з іншими правоохоронними органами України, зокрема Національною поліцією, НАБУ, НАЗК ТОщО;

- проведення активної роз'яснювальної роботи як серед службовців державної податкової служби, так і серед громадян.

Висновки. Отже, завершуючи представлене наукове дослідження, слід узагальнити, що найбільш перспективними тенденціями удосконалення публічно-сервісної діяльності Державної податкової служби України в умовах європейської інтеграції $\epsilon:$ 1) покращення інформаційного забезпечення податкових органів; 2) поліпшення матеріально-технічного забезпечення Державної податкової служби; 3) вдосконалення заходів із протидії корупції в органах ДПС. Ми переконані, що робота законодавця та Державної податкової служби України в зазначених напрямах дасть змогу якісно покращити публічно-сервісну діяльність цього центрального органу виконавчої влади, а також наблизити іï до тих вимог та стандартів, які висувають до української держави європейська та світова спільнота.

\section{Література}

1. Федотова І.О. Актуальні питання правового забезпечення публічно-сервісної діяльності Міністерства доходів і зборів України у галузі митної справи. Публічне право. 2014. № 1. С. 47-53.

2. Петров Є.В. Інформація як об'єкт цивільно-правових відносин : автореф. дис. на здобуття наук. ступеня канд. юрид. наук : 12.00.03 «Цивільне право і цивільний процес; сімейне право; міжнародне приватне право». Харків, 2003. 20 c.

3. Годун В.М., Орленко Н.С., Сендзюк М.А. Інформаційні системи і технології в статистиці : навчальний посібник / За ред. д-ра екон. наук, проф. В.Ф. Ситника. Київ : KHEY, 2003. 267 c.

4. Сулік Н.I. Інформаційна система як організаційний ресурс інформаційного забезпечення організацій. Актуальні проблеми міжнародних відносин. Київ, 2003. Вип. 41, ч. 2. С. 192-197.

5. Корнієнко Г.С. Правове регулювання матеріально-технічного забезпечення сільськогосподарських това- ровиробників в умовах реформування АПК : дис. ... канд. юрид. наук : 12.00.06. Київ, 2003. 190 с.

6. Конопльов В.В. Організаційно-правовий механізм підготовки та прийняття управлінських рішень в адміністративній діяльності органів внутрішніх справ : дис. ... д-ра юрид. наук : 12.00.07. Харків, 2006. 424 с.

7. Болтянська Л.О., Андреева Л.О., Лисак О.І. Економіка підприємства : навчальний посібник. Херсон : ОЛДІ-ПЛЮС, 2015. 668 с.

8. Невмержицький Є.В. Корупція в Україні: причини, наслідки, механізми протидії : монографія. Київ : КНT, 2008. 368 c.

9. Невмержицький Є.В. Корупція як соціально-політичний феномен : дис. ... д-ра політ. наук : спец. 23.00.02 «Політичні інститути та процеси»; НАН України, Ін-т політ. і етнонац. дослідж. ім. І.Ф. Кураса. Київ, 2009. 408 c.

10. Телешун С.О. Роль ефективної антикорупційної політики у формуванні правової держави / С.О. Телешун, І.В. Рейтерович, А.Л. Тіньков. Роль правоохоронних органів у формуванні правової держави в умовах євроінтеграції України : мат-ли Всеукр. підсумк. наук.-практ. конф. (Київ, 12 берез. 2015 р.). Ч. 1. Київ : Нац. акад. внутр. справ, 2015. С. 24-30.

11. Мельник M.І. ЗМІ і влада в Україні: як подолати корупцію? / М.І. Мельник, В. Постільга. Національна безпека й оборона. 2001. № 1. С. 84-88.

12. Мельник М.І. Кримінологічні та кримінально-правові проблеми протидії корупції : дис. ... доктора юрид. наук : спец. 12.00.08 «Кримінальне право та кримінологія; кримінально-виконавче право» ; Національна академія внутрішніх справ України, 2002. 38 с.

13. Мельник М.І. Кримінологічні та кримінально-правові проблеми протидії корупції : автореф. дис... д-ра юрид. наук : 12.00.08. Нац. акад. внутр. справ України. Київ, 2002. 31 c.

14. Реформа ДФС: підвищення ефективності апеляційних оскаржень та зменшення корупції. URL: http: / / www.ukrainepravo.com/news/ukraine/reformadfs-p-dvishchennya-efektivnost-apelyats-ynikh-oskarzhen-tazmenshennya-korupts- $/$.

15. Петрова І.П. Протидія корупції в діяльності Державної фіскальної служби України. Ужгород : ДВНЗ «Ужгородський національний університет». 2016. C. 219-222.

Крилов Д. В., доктор економічних наук, докторант Науково-дослідного інституту публічного права 